\title{
eHealth Delivery of Educational Content Using Selected Visual Methods to Improve Health Literacy on Lifestyle-Related Diseases: Literature Review
}

\author{
Azusa Aida ${ }^{1,2}$, MD; Thomas Svensson ${ }^{1,3,4}$, MD, PhD; Akiko Kishi Svensson ${ }^{1,2,3}$, MD, PhD; Ung-Il Chung ${ }^{1,4,5}$, MD, \\ $\mathrm{PhD}$; Toshimasa Yamauchi ${ }^{2}, \mathrm{MD}$

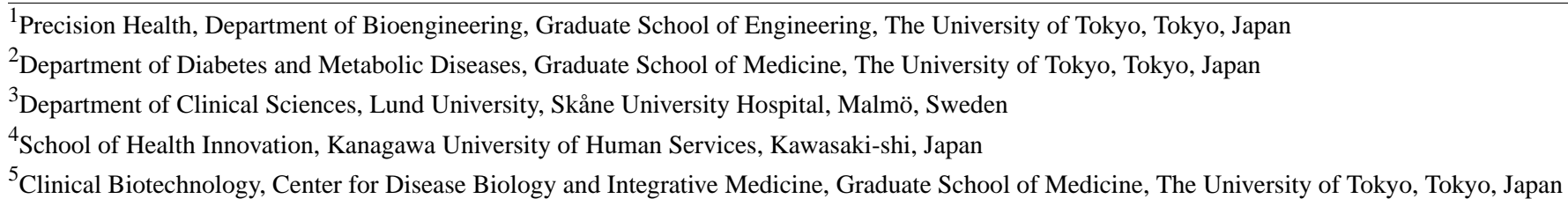

\section{Corresponding Author:}

Thomas Svensson, MD, PhD

Precision Health

Department of Bioengineering

Graduate School of Engineering, The University of Tokyo

7-3-1 Hongo

Bunkyo-ku

Tokyo, 113-8656

Japan

Phone: 81358414737

Email: thomas.svensson@med.lu.se

\section{Abstract}

Background: Lifestyle-related diseases, such as stroke, heart disease, and diabetes, are examples of noncommunicable diseases. Noncommunicable diseases are now the leading cause of death in the world, and their major causes are lifestyle related. The number of eHealth interventions is increasing, which is expected to improve individuals' health literacy on lifestyle-related diseases.

Objective: This literature review aims to identify existing literature published in the past decade on eHealth interventions aimed at improving health literacy on lifestyle-related diseases among the general population using selected visual methods, such as educational videos, films, and movies.

Methods: A systematic literature search of the PubMed database was conducted in April 2019 for papers written in English and published from April 2, 2009, through April 2, 2019. A total of 538 papers were identified and screened in accordance with the PRISMA (Preferred Reporting Items for Systematic Reviews and Meta-Analyses) flow diagram. Finally, 23 papers were included in this review.

Results: The 23 papers were characterized according to study characteristics (author and year of publication, study design and region where the study was conducted, study objective, service platform, target disease and participant age, research period, outcomes, and research method); the playback time of the educational videos, films, and movies; and the evaluation of the study's impacts on health literacy. A total of 7 studies compared results using statistical methods. Of these, 5 studies reported significant positive effects of the intervention on health literacy and health-related measures (eg, physical activity, body weight). Although most of the studies included educational content aimed at improving health literacy, only 7 studies measured health literacy. In addition, only 5 studies assessed literacy using health literacy measurement tools.

Conclusions: This review found that the provision of educational content was satisfactory in most eHealth studies using selected visual methods, such as videos, films, and movies. These findings suggest that eHealth interventions influence people's health behaviors and that the need for this intervention is expected to increase. Despite the need to develop eHealth interventions, standardized measurement tools to evaluate health literacy are lacking. Further research is required to clarify acceptable health literacy measurements. 
(JMIR Mhealth Uhealth 2020;8(12):e18316) doi: 10.2196/18316

\section{KEYWORDS}

application; educational; eHealth; health literacy; lifestyle-related disease; mHealth; review

\section{Introduction}

\section{Lifestyle-Related Diseases}

Lifestyle-related diseases, such as stroke, heart disease, cancer, diabetes, and chronic respiratory disease, are leading examples of noncommunicable diseases and are now the leading causes of death in the world [1]. Of the top 10 causes of death worldwide in 2016, 6 are considered noncommunicable diseases and accounted for $71 \%$ of all deaths [2]. Lifestyle behaviors (eg, smoking, harmful consumption of alcohol, overeating, lack of exercise) or conditions (eg, overweight or obesity, hypertension, abnormal lipid metabolism, and hyperglycemia) are common risk factors for lifestyle-related diseases $[3,4]$. Lifestyle improvement (eg, high-quality diet, increased exercise) plays an important role in the prevention of lifestyle-related diseases [4,5], and improvement for some conditions can be achieved using eHealth-based interventions [3]. Furthermore, the association between lifestyle behavior and health literacy has been widely recognized $[4,6]$.

\section{Health Literacy}

Health literacy is defined as "people's knowledge, motivation and competences to access, understand, appraise, and apply health information in order to make judgments and take decisions in everyday life concerning healthcare, disease prevention and health promotion to maintain or improve quality of life during the life course" [7]. Low health literacy is associated with poor health outcomes and delayed diagnosis and treatment [8]. For example, people with limited health literacy may experience a distrust of providers, pessimism about treatment, and poor satisfaction with the quality of care, probably due to communication difficulties (understanding verbal directions, signs, and placards as well as complexity of instructions) [8]. Occasionally, these patients find it difficult to navigate their way in health care facilities and are therefore unable to receive primary prevention [9]. Conversely, an improvement in health literacy is associated with better health outcomes, such as changes in risk for chronic disease, a reduction in reported disease severity, and decreases in the number of emergency department visits and hospitalizations [10]. Improving health literacy could even expand and extend people's lives in the social, cultural, and work dimensions [7,11]. High rates of low health literacy in populations have prompted governments and national agencies in affected countries to develop national strategies and targets aimed at improving the health literacy of the general population [10].

\section{Information and Communication Technologies, eHealth, and Mobile Health}

The popularity of mobile technologies remains high and the number of users of mobile technologies is increasing [12]. The growing usability of information and communication technologies (ICTs), including mobile apps and web-based applications, can increase the accessibility of health support systems [13-15]. eHealth includes medical information services, including public health services, that are distributed via the internet and related technologies [16]. Mobile health (mHealth) is an expanding area within eHealth and involves the use of mobile computing in the fields of medicine and public health [12]. The use of mHealth services, including smartphone-based services, may benefit health care providers by exerting positive effects on patient education, diagnosis, and management as components of the health delivery processes [12,15]. Smartphones provide a range of functions, including telephone calls, text messages (SMS), photos, video, and web access $[12,17]$.

Educational content to improve individuals' health literacy on lifestyle-related diseases can be offered in many ways, such as group learning, questionnaires, internet-based information searches, and downloadable apps [18-22]. Additionally, smartphone apps provide information through visual methods, such as graphics, videos, and pictures, which facilitate user understanding [14,21-23]. Many children and adults play video games, which include messages and entertaining formats and may lead users to change their health behaviors [18,24]. Accordingly, we wanted to investigate whether videos, games, and pictures are effective in increasing health awareness.

\section{Objectives}

The aims of this review are to identify literature published in the past decade on eHealth interventions that aimed to improve health literacy on lifestyle-related diseases among the general population using selected visual methods, such as videos, films, and movies. Specifically, our review seeks to categorize study characteristics and the evaluation of the studies' impacts on health literacy. Four main themes are discussed in this review: target age, measurement of health literacy, dietary health behavior, and the future directions of eHealth interventions.

\section{Methods}

This literature review was performed using a systematic search and was conducted to emphasize the integration of studies across broader topics [3], with reference to PRISMA (Preferred Reporting Items for Systematic Reviews and Meta-Analyses) $[25,26]$. The search strategy was developed on April 2, 2019, by AA and TS, who also conducted the search.

Details of the search strategy, study selection, and extraction of information can be found in Multimedia Appendix 1. In brief, PubMed was searched in the title and abstract fields using search terms that covered 5 main domains: "digital health," "mHealth," "education," "health literacy," and "visual methods." The search identified 538 papers, with no duplicates (Figure 1). All papers were screened using a 2 -stage process. In the first stage, 373 papers that did not meet the inclusion criteria were excluded. In the second stage, an additional 49 papers were excluded. The full texts of the 116 remaining papers were further surveyed, 
resulting in the exclusion of 93 papers, thereby leaving a total of 23 papers to review.

Figure 1. PRISMA flow diagram of the paper selection process. PRISMA: Preferred Reporting Items for Systematic Reviews and Meta-Analyses.

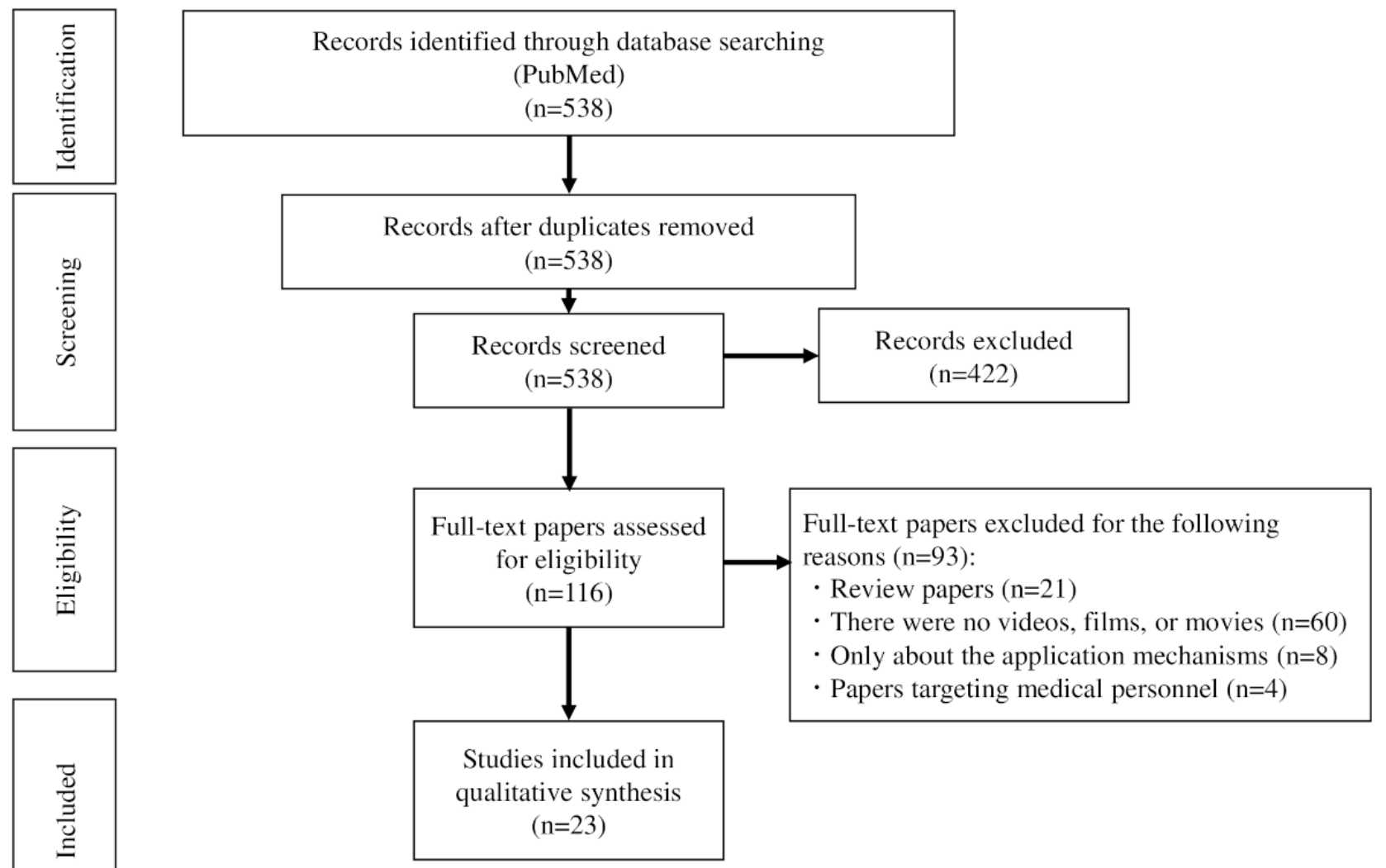

A data-charting form was created to categorize the included studies, the study characteristics (author and year of publication, study design and region where the study was conducted, study objective, target disease and participant age, research period, outcomes, and research method); the playback time of the educational videos, films, and movies; and the evaluation of the study's impacts on health literacy (measurement to assess health literacy).

\section{Results}

\section{Characteristics of the Included Studies}

The included studies are characterized in Multimedia Appendix 2. Of the 23 papers we explored, 13 [18,27-38] were conducted in 2 stages, namely app development followed by intervention research. Two studies conducted randomized controlled trials (RCTs) [27,39], of which 1 [27] described the study protocol only. In addition, 8 studies were pilot studies [28-32,40-42], 6 studies were feasibility studies [33-38], 1 was an intervention study [43], and 1 was a cohort study using qualitative and quantitative methods [44]. As shown in Multimedia Appendix 3 , primary outcomes were measured and the results were reported in 1 RCT [39], 1 intervention study [43], 5 pilot studies [30,31,40-42], and 2 feasibility studies [34,36]. A total of 7 studies [30,34,39-43] investigated the results statistically, of which 5 studies [31,34,39,40,43] reported significant positive effects on health literacy $[34,39,43]$, and health-related measures (eg, physical activity, body weight) $[30,41]$.
In addition, 3 noninterventional studies $[18,45,46]$ were included because their main topics were video games, which was consistent with our search term of apps that included "games."

\section{Study Objectives and Target Diseases}

The objectives of the included studies were categorized into 3 groups: (1) health promotion, (2) disease prevention, and (3) disease management related to the target diseases.

One study [40] was conducted for health promotion and was an innovative mHealth cardiovascular health promotion program, 9 studies [18,27,30,33-35,45-47] aimed to prevent disease by reducing the risks for the diseases, 4 studies $[18,34,45,46]$ promoted smoking cessation for smokers, 2 studies promoted weight loss to address obesity [30,33], 2 studies promoted diet and exercise to lower blood glucose levels in order to manage prediabetes [27,35], and 1 study [47] promoted physical activity to prevent lifestyle-related diseases.

A total of 15 studies [27-29,31,32,35-39,41-44,48] aimed to manage a disease, including diabetes $(n=6)[27,31,35,38,42,43]$ (1 study targeted type 1 diabetes [42] and the remainder targeted type 2 diabetes $[27,31,35,43,47])$, heart failure $(n=3)[41,44,48]$, cardiovascular disease $(n=2)[28,32]$, stroke $(n=2)[36,37]$, gout $(n=1)$ [29], chronic obstructive pulmonary disease $(n=1)$ [38], and osteoarthritis of the knee $(n=1)$ [39]. 


\section{Outcomes}

Outcomes were investigated in 18 studies [18,27,29-36,38-44,48] and categorized into 2 types: (1) changes in measured values and (2) changes in dietary health behaviors.

Studies used a number of measured values: body weight $[27,29,30,33,41,44,48]$, waist circumference [27,30], blood pressure [27,44], oxygen usage [38,44], hemoglobin $\mathrm{A}_{1 \mathrm{c}}$ $[27,38,42]$, serum uric acid [29], and knowledge about health conditions (eg, diabetes knowledge, self-efficacy score, cardiovascular health knowledge, smoking knowledge) $[31,34,39,40,42,43]$. Studies also investigated behavioral changes, smoking attitude [18,34], nutrition [33,35,38,40], physical activity [33,35,38,41], stress [33], medication [32,38], specific health behavior [27], and usability and acceptability of the intervention $[30,36]$.

To assess changes in measured values, individuals' health literacy was tested in 7 studies $[31,34,39,40,42,43,48]$, and measurement tools were used in 5 studies only $[31,34,40,42,43]$. A 27-item questionnaire based on the Norwegian National Health Informatics' diabetes quiz to test theoretical knowledge was conducted for individuals aged 13 to 19 years with type 1 diabetes. The eHealth Literacy Scale (eHEALS) [40] and smoking knowledge score [34] were used for participants 18 years or older. The Rapid Estimate in Adult Literacy in Medicine (REALM) [31], the Diabetes Self-Efficacy Scale [31], and 2 types of study knowledge tests $[39,48]$ were used for participants older than 40 years.

\section{Platform of Development of eHealth Service}

We categorized the included studies into 3 types of platforms: (1) applications (web-based applications or mobile apps), (2) websites, and (3) others.

Various apps were used in 22 studies [18,27-37,39-48]. Apps allow users to use interactive content $[30,32,39,43]$, telephone interviews [44], face-to-face video conferencing [33,40,44], and social network service messages [42]. User satisfaction was evaluated for the intervention itself and for opinions on future development in 16 studies [18,30-32,34-37,39,41,42,44-48]. The 14 apps [18,28-32,34,37,39,41,42,44,45,48] receiving the highest satisfaction and appreciation ratings included those providing educational content (about diseases [30-32,34,39,41,48], through a diary program [29,42], and in game content $[18,45,46])$ using pictures, graphics [27,29,30,34,37,42,44], videos [18,27-31,33-37,39,41-45,47], icons, drawings, animations [47], and an avatar [48]. Only one app providing educational video [30] was considered unacceptable because the process of downloading and viewing the video was too difficult or took too much time.

By connecting with a wearable device [28], sensing devices (eg, blood pressure monitor, weight scales, pulse oximeter) [44], and Bluetooth [42], health information (eg, physical activity, blood glucose values) could be provided remotely.

Websites were based on a textual design to provide educational messages but, unlike apps, were unable to include a gaming component to provide some type of feedback-based reward [45].
Another platform [38] developed internet-enabled home programs that provided educational videos, individual consultations, and a health diary remotely using the patient's television at home and a connection to a computer.

\section{Discussion}

In this review, we aimed to identify and characterize the features of existing literature describing eHealth interventions that aimed to improve health literacy on lifestyle-related diseases among the general population using selected visual methods, such as videos, films, and movies. Through this research, we identified 4 themes, which we discuss here with their strengths and limitations.

\section{Target Age}

We found a difference in target age compared with previous studies focused on health literacy. Kim and Xie [14] found that health literacy was limited in individuals older than 65 years. In this review, 19 studies [27-36,38-42,44,45,47,48] included participants younger than 65 years. Although it appears that people with low health literacy are older [49,50], young adults also lack health literacy, including eHealth literacy [51,52].

In our review, we identified various ideas to facilitate the use of educational content to improve participants' health literacy and found that the kind of educational content provided was required to change as the age range of the target population widened. The use of icons and avatars facilitated usage for both younger and older individuals with low health literacy $[41,48]$. The younger the target age, the greater the acceptability of games [46].

\section{Measurement of Health Literacy}

Measurement tools for health literacy have yet to be established. Indeed, in this review, among the 22 included studies that developed apps for education [18,27-37,39-48], only 5 studies $[31,34,40,42,43]$ used instruments to measure health literacy.

According to a review [14] that identified the relevant literature and examined the instruments used to measure individual health literacy levels, most studies used the eHEALS [53] and the Short Test of Functional Health Literacy (S-TOFHLA) [54]. The S-TOFHLA is a shortened version of the Test of Functional Health Literacy [55], which correlates with the REALM [56]. In another systematic review of health literacy using web-based health information environments [26], the Newest Vital Sign was used most often [57], followed by the REALM [58]. There is a lack of standard measurement tools to evaluate health literacy [17,22,59-62]. Additional research is required to identify measurement methods suitable for evaluating levels of health literacy.

\section{Dietary Health Behavior Change}

Improvements to lifestyle play an important role in lifestyle-related diseases [4,5]. Although 12 included studies $[18,27,30,32-36,38,40,41,44]$ had changes in dietary health behavior as an outcome, none described the mechanism of the relationship between the eHealth intervention and the dietary health behavior. One study [32] classified an educational interventional app in terms of behavior change techniques 
(BCTs) used in behavior change interventions. Future research to investigate the underlying mechanism of BCTs will be useful in clarifying which interventions are likely to be effective.

\section{Future Directions of eHealth Interventions}

Based on user evaluations of the interventions and opinions on their future development, eHealth interventions using visual methods and interactive approaches improve user motivation to improve lifestyle and health literacy. However, 1 study [30] reported that the use of educational videos was not acceptable due to the difficulty older participants experienced in using the mobile app. Future eHealth-based interventions will be required to improve users' computer literacy and identify the mediating effects of age and sex.

\section{Strengths and Limitations}

To our knowledge, this study is the first to review the educational content of eHealth aimed at improving individuals' health literacy on lifestyle-related diseases. Our findings may provide a new perspective on the development of apps that use eHealth to address lifestyle-related diseases and improve people's health literacy.

Several limitations of our study warrant mention. One limitation is the search process: we searched only a single database and included only studies written in English and published in the decade up to April 2019. As discussed in other review papers about eHealth-based interventions [3,14], selecting from additional databases that include unpublished studies is useful for a broader review and should be a consideration for any future systematic review on the topic. Nevertheless, the search was conducted in a systematic manner using the PRISMA flow diagram [25,26]. Additionally, we excluded review papers; papers about AIDS, cancer, psychiatric conditions, odontology, and pediatrics; papers whose target populations were medical personnel and pregnant women; and papers that did not include educational videos, films, or movies. This strategy may have been too strict and some relevant papers may have been missed. Future reviews should be based on wider search criteria.

\section{Conclusions}

Our review provides an overview of the relationships between eHealth-based interventions with selected visual methods, such as videos, films, and movies, and improved health outcomes (ie, changes in measured values and dietary health behavior). Despite the necessity of self-management systems using ICT to control lifestyle-related diseases, relatively few studies have explored educational videos, films, and movies aimed at improving health outcomes.

We also found that the concept of literacy and the tools used to measure the outcome of health literacy-related interventions have not been unified. To more accurately evaluate levels of health literacy and the effects of interventions, future studies need to clarify the concept of health literacy and develop health literacy screening tools.

\section{Acknowledgments}

We thank all staff members at the Center of Innovation, University of Tokyo, as well as all members of Precision Health, University of Tokyo for their support.

This research was supported by the Center of Innovation Program from the Japan Science and Technology Agency (grant No. JPMJCE1304).

\section{Conflicts of Interest}

None declared.

\section{Multimedia Appendix 1}

Supplementary methods.

[DOCX File, 23 KB-Multimedia Appendix 1]

\section{Multimedia Appendix 2}

Characteristics of the included studies.

[DOCX File , 47 KB-Multimedia Appendix 2]

\section{Multimedia Appendix 3}

Summary of the study design, intervention, and the results of the included randomized controlled trial (RCT), intervention study, pilot studies, and feasibility studies.

[DOCX File, 25 KB-Multimedia Appendix 3]

\section{References}

1. Noncommunicable diseases. World Health Organization. URL: https://www.who.int/gho/ncd/en/ [accessed 2020-06-29]

2. The Top 10 causes of death. World Health Organization. URL: https://www.who.int/news-room/fact-sheets/detail/ the-top-10-causes-of-death [accessed 2020-07-14] 
3. Kankanhalli A, Shin J, Oh H. Mobile-Based Interventions for Dietary Behavior Change and Health Outcomes: Scoping Review. JMIR Mhealth Uhealth 2019 Jan 21;7(1):e11312 [FREE Full text] [doi: 10.2196/11312] [Medline: 30664461]

4. Davey J, Holden CA, Smith BJ. The correlates of chronic disease-related health literacy and its components among men: a systematic review. BMC Public Health 2015 Jun 26;15:589 [FREE Full text] [doi: 10.1186/s12889-015-1900-5] [Medline: 26112264]

5. Yamanaka-Okumura H, Tatano H, Kajiura D, Yamaguchi C, Masuda M, Taketani Y. [Key treatment of lifestyle-related diseases: nutritional education and practice]. Clin Calcium 2016 Mar;26(3):441-446. [Medline: 26923983]

6. Risk factors contributing to chronic disease. Australian Institute of Health and Wellness. 2012. URL: https://www.aihw.gov.au/ getmedia/74121d1b-69ca-4a34-a08a-51b741ea26b2/12724.pdf.aspx?inline=true [accessed 2020-04-29]

7. Sørensen K, Van DBS, Fullam J, Doyle G, Pelikan J, Slonska Z, (HLS-EU) Consortium Health Literacy Project European. Health literacy and public health: a systematic review and integration of definitions and models. BMC Public Health 2012;12:80 [FREE Full text] [doi: 10.1186/1471-2458-12-80] [Medline: 22276600]

8. Paasche-Orlow MK, Wolf MS. The causal pathways linking health literacy to health outcomes. Am J Health Behav 2007;31(Suppl 1):S19-S26. [doi: 10.5555/ajhb.2007.31.supp.S19] [Medline: 17931132]

9. Baker DW, Parker RM, Williams MV, Pitkin K, Parikh NS, Coates W, et al. The health care experience of patients with low literacy. Arch Fam Med 1996 Jun;5(6):329-334. [doi: 10.1001/archfami.5.6.329] [Medline: 8640322]

10. Nutbeam D, McGill B, Premkumar P. Improving health literacy in community populations: a review of progress. Health Promot Int 2018 Oct 01;33(5):901-911. [doi: 10.1093/heapro/dax015] [Medline: 28369557]

11. Baur C, Harris L, Squire E. The U.S. National Action Plan to Improve Health Literacy: A Model for Positive Organizational Change. Stud Health Technol Inform 2017;240:186-202. [Medline: 28972518]

12. Free C, Phillips G, Watson L, Galli L, Felix L, Edwards P, et al. The effectiveness of mobile-health technologies to improve health care service delivery processes: a systematic review and meta-analysis. PLoS Med 2013 Jan;10(1):e1001363 [FREE Full text] [doi: 10.1371/journal.pmed.1001363] [Medline: 23458994]

13. Peterson PE, Kwan S. The 7th WHO Global Conference on Health Promotion - towards integration of oral health (Nairobi, Kenya 2009). Community Dent Health 2010;27(3)(suppl 1):129-136. [doi: 10.1922/CDH_2643Petersen08]

14. Kim H, Xie B. Health literacy in the eHealth era: A systematic review of the literature. Patient Educ Couns 2017 Jun;100(6):1073-1082. [doi: 10.1016/j.pec.2017.01.015] [Medline: 28174067]

15. Mosa ASM, Yoo I, Sheets L. A systematic review of healthcare applications for smartphones. BMC Med Inform Decis Mak 2012;12:67 [FREE Full text] [doi: 10.1186/1472-6947-12-67] [Medline: 22781312]

16. Eysenbach G. What is e-health? J Med Internet Res 2001 Jun;3(2):e20 [FREE Full text] [doi: 10.2196/jmir.3.2.e20] [Medline: 11720962]

17. Ownby RL, Acevedo A, Waldrop-Valverde D, Jacobs RJ, Caballero J, Davenport R, et al. Development and initial validation of a computer-administered health literacy assessment in Spanish and English: FLIGHT/VIDAS. Patient Relat Outcome Meas 2013;4:21-35 [FREE Full text] [doi: 10.2147/PROM.S48384] [Medline: 23990736]

18. Bindoff I, de Salas K, Peterson G, Ling T, Lewis I, Wells L, et al. Quittr: The Design of a Video Game to Support Smoking Cessation. JMIR Serious Games 2016 Dec 01;4(2):e19 [FREE Full text] [doi: 10.2196/games.6258] [Medline: 27908844]

19. Levin-Zamir D, Bertschi I. Media Health Literacy, eHealth Literacy, and the Role of the Social Environment in Context. Int J Environ Res Public Health 2018 Dec 03;15(8) [FREE Full text] [doi: 10.3390/ijerph15081643] [Medline: 30081465]

20. Paige SR, Alber JM, Stellefson ML, Krieger JL. Missing the mark for patient engagement: mHealth literacy strategies and behavior change processes in smoking cessation apps. Patient Educ Couns 2018 May;101(5):951-955. [doi:

10.1016/j.pec.2017.11.006] [Medline: 29153592]

21. Sox CM, Gribbons WM, Loring BA, Mandl KD, Batista R, Porter SC. Patient-centered design of an information management module for a personally controlled health record. J Med Internet Res 2010;12(3):e36 [FREE Full text] [doi: 10.2196/jmir.1269] [Medline: 20805091]

22. Yost KJ, Webster K, Baker DW, Jacobs EA, Anderson A, Hahn EA. Acceptability of the talking touchscreen for health literacy assessment. J Health Commun 2010;15(Suppl 2):80-92 [FREE Full text] [doi: 10.1080/10810730.2010.500713] [Medline: 20845195]

23. Choi J, Bakken S. Web-based education for low-literate parents in Neonatal Intensive Care Unit: development of a website and heuristic evaluation and usability testing. Int J Med Inform 2010 Aug;79(8):565-575 [FREE Full text] [doi: 10.1016/j.ijmedinf.2010.05.001] [Medline: 20617546]

24. Lenhart A, Kahne J, Middaugh E, Rankin Macgill A, Evans C, Vitak J. Teens, video games, and civics: teens' gaming experiences are diverse and include significant social interaction and civic engagement. Pew Internet and American Life Project. 2008. URL: https://www.pewresearch.org/internet/wp-content/uploads/sites/9/2008/09/PI 2008.09. 16 teens-video-games REPORT.pdf [accessed 2020-06-23]

25. Moher D, Liberati A, Tetzlaff J, Altman DG. Preferred reporting items for systematic reviews and meta-analyses: the PRISMA statement. J Clin Epidemiol 2009 Oct;62(10):1006-1012. [doi: 10.1016/j.jclinepi.2009.06.005] [Medline: 19631508]

26. Huhta A, Hirvonen N, Huotari M. Health literacy in web-based health information environments: systematic review of concepts, definitions, and operationalization for measurement. J Med Internet Res 2018 Dec 19;20(12):e10273 [FREE Full text] [doi: $\underline{10.2196 / 10273}$ ] [Medline: $\underline{30567690}$ ] 
27. Sarfati D, McLeod M, Stanley J, Signal V, Stairmand J, Krebs J, et al. BetaMe: impact of a comprehensive digital health programme on HbA1c and weight at 12 months for people with diabetes and pre-diabetes: study protocol for a randomised controlled trial. Trials 2018 Mar 05;19(1):161 [FREE Full text] [doi: 10.1186/s13063-018-2528-4] [Medline: 29506562]

28. Ceasar JN, Claudel SE, Andrews MR, Tamura K, Mitchell V, Brooks AT, et al. Community Engagement in the Development of an mHealth-Enabled Physical Activity and Cardiovascular Health Intervention (Step It Up): Pilot Focus Group Study. JMIR Form Res 2019 Jan 04;3(1):e10944 [FREE Full text] [doi: 10.2196/10944] [Medline: 30684422]

29. Nguyen AD, Frensham LJ, Wong MX, Meslin SM, Martin P, Lau AY, et al. mHealth App Patient Testing and Review of Educational Materials Designed for Self-Management of Gout Patients: Descriptive Qualitative Studies. JMIR Mhealth Uhealth 2018 Oct 15;6(10):e182 [FREE Full text] [doi: 10.2196/mhealth.9811] [Medline: 30322835]

30. Choo S, Kim JY, Jung SY, Kim S, Kim JE, Han JS, et al. Development of a Weight Loss Mobile App Linked With an Accelerometer for Use in the Clinic: Usability, Acceptability, and Early Testing of its Impact on the Patient-Doctor Relationship. JMIR Mhealth Uhealth 2016;4(1):e24 [FREE Full text] [doi: 10.2196/mhealth.4546] [Medline: 27032541]

31. Wood FG, Alley E, Baer S, Johnson R. Interactive Multimedia Tailored to Improve Diabetes Self-Management. Nurs Clin North Am 2015 Sep;50(3):565-576. [doi: 10.1016/j.cnur.2015.05.009] [Medline: 26333610]

32. Boyd AD, Moores K, Shah V, Sadhu E, Shroff A, Groo V, et al. My Interventional Drug-Eluting Stent Educational App (MyIDEA): Patient-Centered Design Methodology. JMIR Mhealth Uhealth 2015;3(3):e74 [FREE Full text] [doi: 10.2196/mhealth.4021] [Medline: 26139587]

33. Materia FT, Smyth JM, Heron KE, Hillemeier M, Feinberg ME, Fonzi P, et al. Preconceptional health behavior change in women with overweight and obesity: prototype for SMART strong healthy women intervention. Mhealth 2018;4:24 [FREE Full text] [doi: 10.21037/mhealth.2018.06.06] [Medline: $\underline{\text { 30148139] }}$

34. Finkelstein J, Cha EM. Using a Mobile App to Promote Smoking Cessation in Hospitalized Patients. JMIR Mhealth Uhealth 2016 May 06;4(2):e59 [FREE Full text] [doi: 10.2196/mhealth.5149] [Medline: 27154792]

35. Fontil V, McDermott K, Tieu L, Rios C, Gibson E, Sweet CC, et al. Adaptation and Feasibility Study of a Digital Health Program to Prevent Diabetes among Low-Income Patients: Results from a Partnership between a Digital Health Company and an Academic Research Team. J Diabetes Res 2016;2016:8472391 [FREE Full text] [doi: 10.1155/2016/8472391] [Medline: 27868070 ]

36. Sureshkumar K, Murthy G, Natarajan S, Naveen C, Goenka S, Kuper H. Evaluation of the feasibility and acceptability of the 'Care for Stroke' intervention in India, a smartphone-enabled, carer-supported, educational intervention for management of disability following stroke. BMJ Open 2016 Feb 02;6(2):e009243 [FREE Full text] [doi: 10.1136/bmjopen-2015-009243] [Medline: 26839011]

37. Sureshkumar K, Murthy GVS, Munuswamy S, Goenka S, Kuper H. 'Care for Stroke', a web-based, smartphone-enabled educational intervention for management of physical disabilities following stroke: feasibility in the Indian context. BMJ Innov 2015 Jul;1(3):127-136 [ [FREE Full text] [doi: 10.1136/bmjinnov-2015-000056] [Medline: 26246902]

38. Burkow TM, Vognild LK, Østengen G, Johnsen E, Risberg MJ, Bratvold A, et al. Internet-enabled pulmonary rehabilitation and diabetes education in group settings at home: a preliminary study of patient acceptability. BMC Med Inform Decis Mak 2013 Mar 05;13:33 [FREE Full text] [doi: 10.1186/1472-6947-13-33] [Medline: 23496829]

39. Timmers T, Janssen L, Pronk Y, van der Zwaard BC, Koëter S, van Oostveen D, et al. Assessing the Efficacy of an Educational Smartphone or Tablet App With Subdivided and Interactive Content to Increase Patients' Medical Knowledge: Randomized Controlled Trial. JMIR Mhealth Uhealth 2018 Dec 21;6(12):e10742 [FREE Full text] [doi: 10.2196/10742] [Medline: 30578185]

40. Brewer LC, Jenkins S, Lackore K, Johnson J, Jones C, Cooper LA, et al. mHealth Intervention Promoting Cardiovascular Health Among African-Americans: Recruitment and Baseline Characteristics of a Pilot Study. JMIR Res Protoc 2018 Jan 31;7(1):e31 [FREE Full text] [doi: 10.2196/resprot.8842] [Medline: 29386174]

41. Lloyd T, Buck H, Foy A, Black S, Pinter A, Pogash R, et al. The Penn State Heart Assistant: A pilot study of a web-based intervention to improve self-care of heart failure patients. Health Informatics J 2019 Jun;25(2):292-303. [doi:

10.1177/1460458217704247] [Medline: 28504048]

42. Frøisland DH, Arsand E, Skårderud F. Improving diabetes care for young people with type 1 diabetes through visual learning on mobile phones: mixed-methods study. J Med Internet Res 2012;14(4):e111 [FREE Full text] [doi: 10.2196/jmir.2155] [Medline: 22868871]

43. Alanzi T, Bah S, Alzahrani S, Alshammari S, Almunsef F. Evaluation of a mobile social networking application for improving diabetes Type 2 knowledge: an intervention study using WhatsApp. J Comp Eff Res 2018 Sep;7(9):891-899. [doi: 10.2217/cer-2018-0028] [Medline: 29943647]

44. Triantafyllidis A, Velardo C, Chantler T, Shah SA, Paton C, Khorshidi R, SUPPORT-HF Investigators. A personalised mobile-based home monitoring system for heart failure: The SUPPORT-HF Study. Int J Med Inform 2015 Oct;84(10):743-753. [doi: 10.1016/j.ijmedinf.2015.05.003] [Medline: 26037921]

45. Watson AM, Alber JM, Barnett TE, Mercado R, Bernhardt JM. Content Analysis of Anti-Tobacco Videogames: Characteristics, Content, and Qualities. Games Health J 2016 Jun;5(3):216-223. [doi: 10.1089/g4h.2015.0096] [Medline: 27096576] 
46. BinDhim NF, Freeman B, Trevena L. Pro-smoking apps: where, how and who are most at risk. Tob Control 2015 Mar;24(2):159-161. [doi: 10.1136/tobaccocontrol-2013-051189] [Medline: 24046212]

47. Bender MS, Martinez S, Kennedy C. Designing a Culturally Appropriate Visually Enhanced Low-Text Mobile Health App Promoting Physical Activity for Latinos: A Qualitative Study. J Transcult Nurs 2016 Dec;27(4):420-428. [doi: 10.1177/1043659614565249] [Medline: 25556208]

48. Athilingam P, Osorio RE, Kaplan H, Oliver D, O'neachtain T, Rogal PJ. Embedding Patient Education in Mobile Platform for Patients With Heart Failure: Theory-Based Development and Beta Testing. Comput Inform Nurs 2016 Feb;34(2):92-98. [doi: 10.1097/CIN.0000000000000216] [Medline: 26765655]

49. Choi NG, Dinitto DM. The digital divide among low-income homebound older adults: Internet use patterns, eHealth literacy, and attitudes toward computer/Internet use. J Med Internet Res 2013 May;15(5):e93 [FREE Full text] [doi: 10.2196/jmir.2645] [Medline: 23639979]

50. Watkins I, Xie B. eHealth literacy interventions for older adults: a systematic review of the literature. J Med Internet Res 2014;16(11):e225 [FREE Full text] [doi: 10.2196/jmir.3318] [Medline: 25386719]

51. Janiak E, Rhodes E, Foster AM. Translating access into utilization: lessons from the design and evaluation of a health insurance Web site to promote reproductive health care for young women in Massachusetts. Contraception 2013 Dec;88(6):684-690. [doi: 10.1016/j.contraception.2013.09.004] [Medline: 24120249]

52. Stellefson M, Hanik B, Chaney B, Chaney D, Tennant B, Chavarria EA. eHealth literacy among college students: a systematic review with implications for eHealth education. J Med Internet Res 2011 Dec;13(4):e102 [FREE Full text] [doi: 10.2196/jmir.1703] [Medline: 22155629]

53. Fagnano M, Halterman JS, Conn KM, Shone LP. Health literacy and sources of health information for caregivers of urban children with asthma. Clin Pediatr (Phila) 2012 Mar;51(3):267-273 [FREE Full text] [doi: 10.1177/0009922811421413] [Medline: 21911409]

54. Parker RM, Baker DW, Williams MV, Nurss JR. The test of functional health literacy in adults: a new instrument for measuring patients' literacy skills. J Gen Intern Med 1995 Oct;10(10):537-541. [Medline: $\underline{8576769]}$

55. Smith SS, Piper ME, Bolt DM, Fiore MC, Wetter DW, Cinciripini PM, et al. Development of the Brief Wisconsin Inventory of Smoking Dependence Motives. Nicotine Tob Res 2010 May;12(5):489-499 [FREE Full text] [doi: 10.1093/ntr/ntq032] [Medline: 20231242]

56. Health literacy: report of the Council on Scientific Affairs. Ad Hoc Committee on Health Literacy for the Council on Scientific Affairs, American Medical Association. JAMA 1999 Feb 10;281(6):552-557. [Medline: 10022112]

57. Noblin AM, Wan TTH, Fottler M. The impact of health literacy on a patient's decision to adopt a personal health record. Perspect Health Inf Manag 2012;9:1-13 [FREE Full text] [Medline: 23209454]

58. Schprechman JP, Gathright EC, Goldstein CM, Guerini KA, Dolansky MA, Redle J, et al. Health literacy and global cognitive function predict e-mail but not internet use in heart failure patients. Nurs Res Pract 2013;2013:507910 [FREE Full text] [doi: 10.1155/2013/507910] [Medline: 24282634]

59. Hahn EA, Choi SW, Griffith JW, Yost KJ, Baker DW. Health literacy assessment using talking touchscreen technology (Health LiTT): a new item response theory-based measure of health literacy. J Health Commun 2011;16(Suppl 3):150-162 [FREE Full text] [doi: 10.1080/10810730.2011.605434] [Medline: 21951249]

60. Ownby RL, Waldrop-Valverde D, Hardigan P, Caballero J, Jacobs R, Acevedo A. Development and validation of a brief computer-administered HIV-Related Health Literacy Scale (HIV-HL). AIDS Behav 2013 Feb;17(2):710-718 [FREE Full text] [doi: 10.1007/s10461-012-0301-3] [Medline: 22961499]

61. van Deursen AJAM, van Dijk JAGM. Internet skills performance tests: are people ready for eHealth? J Med Internet Res 2011 Apr;13(2):e35 [FREE Full text] [doi: 10.2196/jmir.1581] [Medline: 21531690]

62. Baker DW. The meaning and the measure of health literacy. J Gen Intern Med 2006 Aug;21(8):878-883 [FREE Full text] [doi: 10.1111/j.1525-1497.2006.00540.x] [Medline: 16881951]

\author{
Abbreviations \\ BCT: behavior change technique \\ eHEALS: eHealth Literacy Scale \\ ICT: information and communication technology \\ mHealth: mobile health \\ RCT: randomized controlled trial \\ REALM: Rapid Estimate in Adult Literacy in Medicine \\ S-TOFHLA: Short Test of Functional Health Literacy
}


Edited by CL Parra-Calderón, L Buis; submitted 21.02.20; peer-reviewed by K Schroeder, A Wickersham; comments to author 14.06.20; revised version received 07.08.20; accepted 19.11.20; published 09.12.20

Please cite as:

Aida A, Svensson T, Svensson AK, Chung UI, Yamauchi T

eHealth Delivery of Educational Content Using Selected Visual Methods to Improve Health Literacy on Lifestyle-Related Diseases: Literature Review

JMIR Mhealth Uhealth 2020;8(12):e18316

URL: http://mhealth.jmir.org/2020/12/e18316/

doi: $\underline{10.2196 / 18316}$

PMID: 33295296

(C)Azusa Aida, Thomas Svensson, Akiko Kishi Svensson, Ung-Il Chung, Toshimasa Yamauchi. Originally published in JMIR mHealth and uHealth (http://mhealth.jmir.org), 09.12.2020. This is an open-access article distributed under the terms of the Creative Commons Attribution License (https://creativecommons.org/licenses/by/4.0/), which permits unrestricted use, distribution, and reproduction in any medium, provided the original work, first published in JMIR mHealth and uHealth, is properly cited. The complete bibliographic information, a link to the original publication on http://mhealth.jmir.org/, as well as this copyright and license information must be included. 